\begin{tabular}{|c|c|c|}
\hline \multirow{2}{*}{8} & $\begin{array}{l}\text { International Journal of Current Research in } \\
\text { Biosciences and Plant Biology }\end{array}$ & $E$ \\
\hline & Volume $5 \bullet$ Number 11 (November-2018) • ISSN: 2349-8080 (Online) & \\
\hline $\begin{array}{l}\text { EXCELLENT } \\
\text { PUBLISHERS }\end{array}$ & Journal homepage: www.ijcrbp.com & \\
\hline
\end{tabular}

Original Research Article

doi: https://doi.org/10.20546/ijcrbp.2018.511.005

\title{
Diversity of Genus Plagiochasma in Satpuda Range of Khandesh Region, Maharashtra, India
}

\author{
Tanveer A. Khan ${ }^{1 *}$ and Javed V. Khan ${ }^{2}$ \\ 1Department of Botany, H. J. Thim College of Arts and Science, Mehrun, Jalgaon-425 001, \\ Maharashtra, India \\ 2Department of Biotechnology, PGCSTR, Jalgaon-425 001, Maharashtra, India \\ *Corresponding author.
}

\begin{tabular}{|c|c|}
\hline Article Info & ABSTRACT \\
\hline & \multirow{4}{*}{$\begin{array}{l}\text { Satpuda range of Khandesh region is an-ignored geographical area by Indian } \\
\text { bryologist. Hence, very little information is available regarding bryoflora of this range. } \\
\text { In this study attempt was made to find out the status of genus Plagiochasma in this } \\
\text { region. Out of } 35 \text { species of Plagiochasma only } 8 \text { are validly reported from the Indian } \\
\text { subcontinent. In present study three species of Plagiochasma viz., Plagiochasma rupestre } \\
\text { Forst, Plagiochasma pterospermum Mass, Plagiochasma appendiculatum Lehm. \& Lindenb. } \\
\text { have been reported for the first time from Satpuda range of Khandesh region of } \\
\text { Maharashtra. The morphotaxonomical details along with their distribution in India } \\
\text { have been given in present paper. }\end{array}$} \\
\hline l: & \\
\hline K & \\
\hline & \\
\hline
\end{tabular}

Satpuda range

\section{Introduction}

Khandesh region consists of three districts Jalgaon, Dhule and Nandurbar. Khandesh lies at the Northwestern corner of the Deccan plateau, in the valley of the Tapti river, and is bounded in the north by the Satpuda ranges, in the east by the Berar (Vidarbha) region, in the south by the hills of Ajanta, belonging to the Marathwada region of Maharashtra, and in the west by the Northern most ranges of the Western Ghats, and beyond that the coastal plain of Gujarat. Khandesh has varied topographical features and landscape. It lies between $20^{\circ} 8^{\prime}$ and $22^{\circ} 7^{\prime}$ North latitude and $73^{\circ} 42^{\prime}$ and $76^{0}$ 28 $8^{\prime}$ East longitude. For administrative purposes, it is distributed over sixteen sub-divisions, with an average area of 1669.12 sq. km, 215 villages and 64,290 inhabitants. Khandesh covers a total area of 26,703.36 sq. km stretching nearly $257.44 \mathrm{Km}$ along. The river Tapti traverses the length of Khandesh from 112 to $144 \mathrm{Km}$. Khandesh forms 
an upland basin of the most northerly section of the Deccan table land. Along the whole northern frontier, the district is bounded by the Satpuda ranges, a mountainous tract from 48.27-64.36 km wide.

Khandesh region though botanically rich in biodiversity have not been explored extensively except a few sporadic reports on floristic of Yadav et al. (2003), Kshirsagar and Patil (2008) and Patil (2003). During bryoflora explorations of Khandesh region of Maharashtra state, 03 interesting specimens belonging to Plagiochasma were collected from wet hill slope and margins of water courses. Close examination with the help of literature and specimens reveal that they were not recorded earlier from Khandesh region. All of them have been identified as Plagiochasma rupestre Forst, Plagiochasma pterospermum Mass, Plagiochasma appendiculatum Lehm. \& Lindenb., which proved to be first report for Satpuda range of Khandesh region of Maharashtra. Identification of all these taxa is confirmed by Bryology Unit (Department of Botany, University of Lucknow), who confirmed the identity of the species.

\section{Materials and methods}

Satpuda ranges, which is one of the major hotspot of plants in Khandesh region. While working on a floristic study of Khandesh region of Maharashtra State, frequent collection tours in every season was undertaken to collect plants. The outcome of the collection tour was the 03 new taxa of bryophytes that are Plagiochasma rupestre Forst., Plagiochasma pterospermum Mass., Plagiochasma appendiculatum Lehm. \& Lindenb.

All taxa have been identified with the help of available literature. The voucher specimens are deposited at the Department of Botany, H.J. Thim College of Arts and Science Mehrun Jalgaon, Maharashtra. The Plagiochasma species have been described with their Latin names, followed by author's citations. Detailed descriptions of the taxa are given.

\section{Results and discussion}

While exploring the study area 3 species of Plagiochasma have been collected from satpuda range of Khandesh region detailed descriptions are given below:

Plagiochasma rupestre (Forst.) Steph. Plagiochasma subgen. Micropylum Bischl., Rev. Bryol. Lichenol. 43: 63-109 (1977); Plagiochasma. (Micropylum) rupestre (Forst.) Steph., Spec. Hep. 1:80 (1899); Alam et al., Indian J. Forestry 32(4): 624 (2009); Aytonia rupestris Forst. Char. Gen. Pl: 148 (1776); Plagiochasma nepalense (Lehm. et Bisch.) Steph., Spec. Hep. 1: 81 (1898); Plagiochasma simlense Kash. (P. simlensis) J. Bombay. Nat. Hist. Soc. 25: 279 (1917). Fig. 1 (A-B).

Thallus dark green 10-12 × 4-5 mm, simple, with apical innovations, edges purple, more or less broad, entire or slightly crenulate. Midrib distinct with closely arranged pores, pores simple, minute, not raised over the surface, about $14-20 \mu \mathrm{m}$ in diameter with a concentric ring of 6 cells. Ventral scales purple-red, appendages broadly triangular 1$2.6 \times 1-1.3 \mathrm{~mm}$, covering the entire ventral surface, narrowly arranged in 2 rows, one on each side of the midrib, with an elongated appendage, $3-6 \times$ $0.08-0.1 \mathrm{~mm}$. Air chambers compact not very distinct, thallus differentiated into assimilatory and storage zone, cells of assimilatory zone thin walled parcnchymatous containing chloroplast. Storage zone cells thin walled and compactly arranged.

Dioicous. Male receptacles sessile, horse-shoe shaped, dorsal, present near the apex of thallus lobe. Female receptacle in median part of thallus all along the midrib, covered with hyaline $(0.50-1.7 \times 0.30$ $0.40 \mathrm{~mm}$ ) receptacular scales at base. Disc of female receptacle usually three lobed. Sporophyte horizontally placed. Capsule wall single layered, cells $20-26 \times 17.2-20.0 \mu \mathrm{m}$, thickened at corners only Spores brown-dark brown, 80-90 $\mu \mathrm{m}$ in diameter, polar, distal face with numerous polygonal areas or alveoli, proximal faces with distinct triradiate mark. Elaters simple or branched, 200-280 × 10-16 $\mu \mathrm{m}$, bitri spirate, yellowish or reddish brown. 

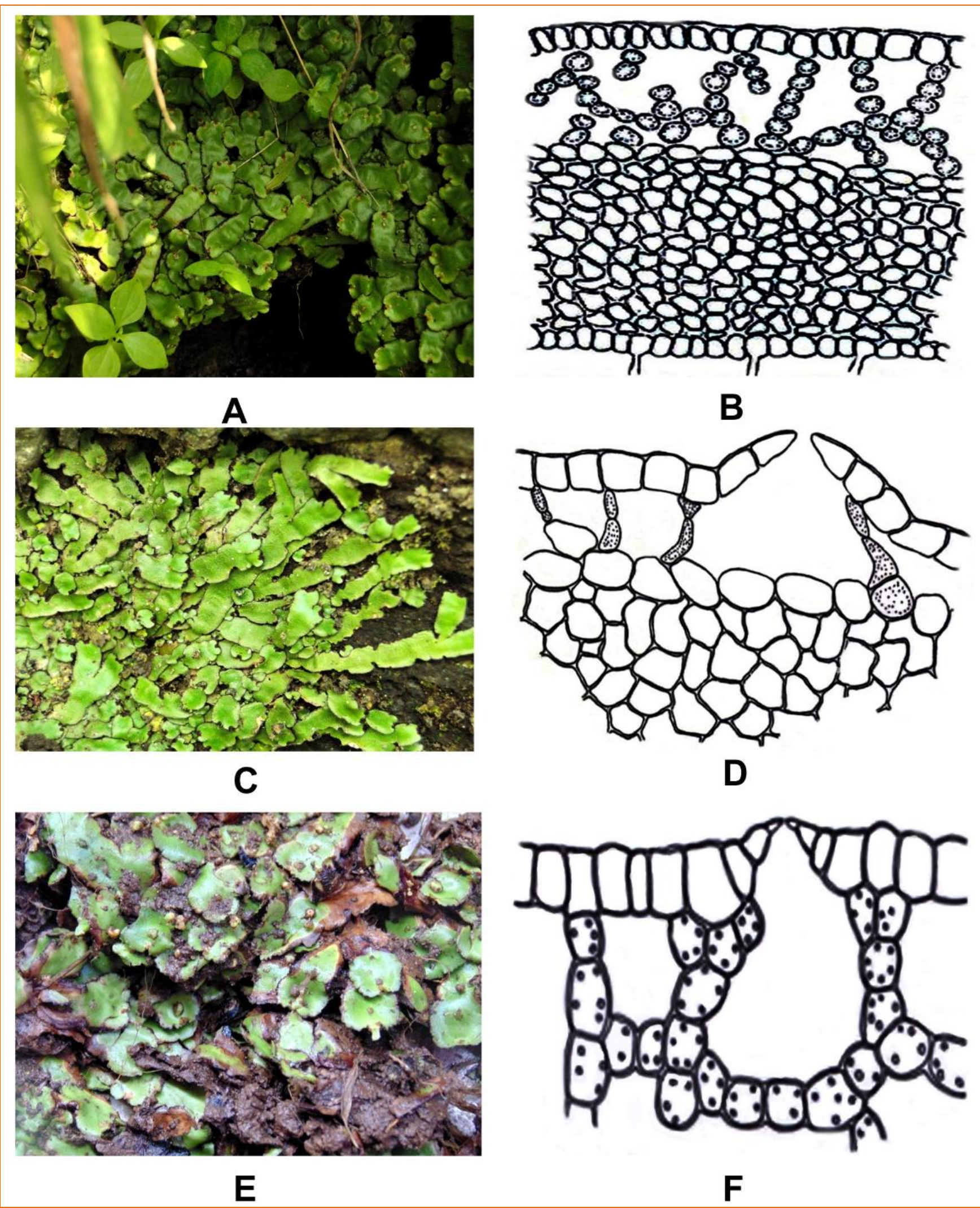

Fig. 1: A-B, Plagiochasma rupestre (Forst.) Steph. A: Plant dorsal view; B: T. S. of thallus; C-D, Plagiochasma pterospermum Mass. C: Plant dorsal view; D: T. S. of thallus; E-F, Plagiochasma appendiculatum Lehm. E: Plant dorsal view; F: T. S. of thallus; 
Distribution: Occasional. In Satpuda ranges. On gravelly, rocky substrate or on rocks along hill slopes.

GPS reading: $\mathrm{N} \quad 21^{\circ} 20^{\prime} 46.30^{\prime \prime}$ E 75'19'28.59" (Elevation 332.6m)

Specimens examined: Jalgaon Dist., Devjiri, TAK 19. Nandurbar Dist., Amlibarighat TAK31; Molgi, TAK 47.

Plagiochasma pterospermum Mass., Mem. Acad. Agrie Verona 73: 46 (1897); Alam et al., Indian J. Forestry 32(4): 631 (2009); Plagiochasma articulatum Kashyap, New Phytol. 13: 320 (1914). Fig. 1 (C-D).

Thallus dark green, 8-32 $\times 5-10 \mathrm{~mm}$, edges purple, extremely undulate, apex notched. Midrib distinct. Dorsal surface of thallus with distantly arranged pores, pore about 28.2 - $30.6 \mu \mathrm{m}$ in diameter, slightly raised, with 3-4 concentric rings of cells, inner most ring made up of 8 cells each. Ventral scales purple, closely arranged, sometimes imbricate, in two rows, one on each side of midrib, with 1 to 5 cells wide 1-3 linear appendages (1.5$2.0 \times 0.5-0.9 \mathrm{~mm})$. Assimilatory zone having air chambers in 5-6 rows at midrib and 2 rows at margins without assimilatory filaments. Storage zone confined to the midrib region.

Monoicous. Male receptacles sessile, horse shoeshaped, dorsal, present near the apex of thallus lobe, with small papillae over the disc. Female receptacle dorsal on thallus, shortly stalked, surrounded by large number of linear receptacular scales; receptacular scales $2.5-5.5 \times 1-1.5 \mathrm{~mm}, 3-5$ cells in width at base. Stalk without rhizoidal furrow. Disc of female receptacle 3-4 lobed, sporophyte horizontally placed. Capsule wall single layered, cells $15-38 \times$ $15-22 \mu \mathrm{m}$ with trigones. Spores tetrahedral, 70-87 $\times$ 80-90 $\mu \mathrm{m}$, distal face with irregularly distributed lamellae. Proximal face with distinct triradiate mark and lesser number of lamellae. Spore surface yellowish brown in colour giving an appearance of wing at the periphery. Elaters $140-280 \times 9-18 \mu \mathrm{m}$, branched, bi - tri spirate, brownish in colour.
Distribution: Rare. In wet patches, besides water streams, along hill slopes.

GPS reading: N 21 $22^{\prime} 37.25^{\prime \prime}$ E 7545'24.97" (Elevation $753.6 \mathrm{~m}$ )

Specimens examined: Jalgaon Dist., Langdha Aamba, TAK 63. Nandurbar Dist., Toranmal, TAK 79; Kalapani, TAK 92.

Plagiochasma appendiculatum Lehm. \& Lindenb. in Lehmann, Novarum et minus cognitarum stirpium pugillus quartus: 14 (1832); Gottsche et al.: 517 (1844-1847); Steph.: 782 (1898); Kashyap: 318 (1914); Perold in Bothalia 25, 1: 13-29 (1995). Fig. 1 (E-F).

Thallus large, flat with edgesinfrequently curved somewhat downwards or upwards, largely ligulate. bright green, shiny surface, with fine purple edge along margins, pores observable, small and slightly elevated, when wet: thallus margins incurved or inflexed, revealing shiny, reddish purple transversely striate and wrinkled underneath of wings, not covered by scales, when dry; in crowded, gregarious patches, simple or once. Branches 12-18 x 5-7 mm. 710-900 $\mu \mathrm{m}$ thick over midrib, laterally thinning out into attenuate wings; apex notched, with reddish or partly hyaline scale appendages recurved over edge in 2 layers: margins acute, thin, somewhat undulate: edges sloping, obliquely, reddish or purple: ventral face medianly keeled, green, with row of purple red scales on either side. Dorsal epidermal cells unistratose, hyaline, rectangular to polygonal. $20-40 \times 15-25$ $\mu \mathrm{m}$. walls thin and thickened at angles, in transverse section 28-35 $\mu \mathrm{m}$ thick, smooth superficially, along margins 2 or more rows of cells, rectangular, up to $20 \mathrm{x} \times 10 \mu \mathrm{m}$ or shorter than broad, $10 \times 20 \mu \mathrm{m}$; air pores not so many, 100-200 $\mu \mathrm{m}$ distant from each other, somewhat elevated, simple, 7-9 $\mu \mathrm{m}$ wide, enclosed by an innermost ring, $2 \mu \mathrm{m}$ wide, of minute collapsed cells and then by 2 , concentric rings of larger cells, 5 or 6 inner ones transversely oval or round. $10-14 \times 13-18 \mu \mathrm{m}$, partly covering outer row of 5 bluntly triangular cells, $20 \times 30 \mu \mathrm{m}$ across widest part, radial walls 
not thickened. Assimilation tissue 350-450 $\mu \mathrm{m}$ thick, air chambers vacant, in many layers, upper ones $\pm 20 \mu \mathrm{m}$ wide, lower down wider, $\pm 60 \mu \mathrm{m}$ wide, cells in bounding walls 35-48 $\times 20-35 \mu \mathrm{m}$. with a brown oil body. 20-30 $\mu \mathrm{m}$ wide: storage tissue occupying ventral $1 / 2$ of thickness of thallus, cells angular, up to $40 \mu \mathrm{m}$ wide; rhizoids also smooth. 12-25 $\mu \mathrm{m}$ wide. Scales red. Appendages typically decolorate, arranged in 2 forwardly directed ventral rows, one on either side of midrib, asymmetric, obtusely triangular with flatly arched base, progressively tapering above, deeply constricted and folded where joined with large, orbicular appendage, the latter up to $700 \mu \mathrm{m}$ long, $500 \mu \mathrm{m}$ across widest part in middle. $310-365 \mu \mathrm{m}$ wide at base, at margin 1 rows of small rectangular cells $10-16 \times 7-12 \mu \mathrm{m}$. alternating with slightly larger cells, in the centre of appendage toward base, cells large, rectangular. $\pm 75 \times 37 \mu \mathrm{m}$ enclosed by numerous rows of irregularly shaped cells; body of scale up to $1200 \mu \mathrm{m}$ long. $11 \mu \mathrm{m}$ across base, cells rectangular. $\pm 60 \times 20 \mu \mathrm{m}$. 5 or 7 smaller, scattered ones with remains of oil bodies. $\pm 26 \times 20 \mu \mathrm{m}$ : at margins cells small, $\pm 24 \times 12 \mu \mathrm{m}$. walls thin, curved, irregularly with long, projecting papillae.

Monoicous, however male and female receptacles frequently on separate plants. Androecia in sessile cushions, oval, horseshoe or heart-shaped. 1.4-2.6 $\times$ $2.0 \mathrm{~mm}$. on leading branch medianly. near apex, proximally partially enclosed by narrow curved groove in thallus. Base encircled by blunt, hyaline or partly purple paleae. $540-570 \times 120-170 \mu \mathrm{m}$. cells rectangular. $\pm 56 \times 20 \mu \mathrm{m}$. toward apex smaller, quadrate. $\pm 23 \times 24 \mu \mathrm{m}$. near to base margins with some projecting papillae. $24 \times 12 \mu \mathrm{m}$. Archegoniophores single or several in acropetal sequence medianly along main branch, firstly surrounded by arching hyaline paleae. $\pm 800 \times 100$ $\mu \mathrm{m}$, lower cells typically rectangular. $35-48 \times 20$ $\mu \mathrm{m}$, toward peak smaller. $\pm 18 \times 14 \mu \mathrm{m}$ and at margin $14 \times 23 \mu \mathrm{m}$, missing papillae. Carpocephala $2 \times 2 \mathrm{~mm}$ when 4 lobes present, elevated on stalk, $1.2-2 \mathrm{~mm}$ long, $\pm 70 \mu \mathrm{m}$ in diameter, in transverse section 1 or 2 rows of cortical cells, $16-26 \times 16-28$ $\mu \mathrm{m}$, medullary cells angular, up to $36 \mathrm{um}$ wide, thin- walled. Spores 70-80 $\mu \mathrm{m}$ diameter, triangularglobular, polar, pale brown, translucent, wing \pm 8 $\mu \mathrm{m}$ wide, margin undulate, minutely crenulate.

GPS reading: N 21o 40' 26.09" E 74o1' 29.68" (Elevation $726.7 \mathrm{~m}$ )

Distribution: Occasional. In Satpuda ranges grow on moist hill slopes.

Specimens examined: Jalgaon Dist., Jamnya, $T A K$ 107. Nandurbar Dist., Dab, TAK 121; Dadgaon, TAK 147.

All pertinent literature were gone through, notably Perold (1995), Alam and Srivastava (2009) and consulted with Dr. Afroz Alam, Department of Bioscience and Biotechnology, Banasthali University Rajasthan. In Khandesh region only floristic surveys other than bryoflora have been done so far by Yadav et al. (2003), Patil (2003), Kshirsagar and Patil (2008), Khan and Chaudhari (2014), and Khan et al. (2015). There is no literature available regarding bryoflora of Satpuda range in the Khandesh region of Maharashtra. It was found that, these species were not reported in any of the Khandesh region. These species are new record for the Satpuda range of Khandesh region of Maharashtra State. The specimens are deposited in the herbarium of Department of Botany, H.J. Thim College of Arts and Science Mehrun Jalgaon. On close examination of specimens and detailed scrutiny of literature published till today on these taxa, it can be claimed that these are new records for Satpuda range of Khandesh region of Maharashtra.

\section{Conclusion}

Plagiochasma rupestre Forst, Plagiochasma pterospermum Mass, Plagiochasma appendiculatum Lehm. \& Lindenb., are to be first report for Satpuda range of Khandesh region of Maharashtra. Data available about these species are meager but field surveys will play important role to enhance knowledge about the Indian Bryology, particularly in Maharashtra. 


\section{Conflict of interest statement}

Authors declare that they have no conflict of interest.

\section{Acknowledgement}

The authors wish to express their gratitude to Dr. Afroz Alam, Department of Bioscience, Banasthali University, Rajasthan, who confirmed the identity of the species and also providing the literature. Thanks are also due to the Principal, H. J. Thim College, Jalgaon, for providing laboratory and library facilities.

\section{References}

Alam, A., Srivastava, S. C., 2009. Current status of genus Plagiochasma in Nilgiri and Palni Hills with semi details of spores. Indian J. For. 32(4), 623-634.
Khan, T. A., Chaudhari, G. S., 2014. New records of Cyperaceae for Khandesh region of Maharashtra, India. Plant Archiv. 14(1), 235-240.

Khan, T. A., Desai, V. V., Gawande, N. R., 2015. Four new flowering plant records from Satpuda range of Jalgaon District, (MS) India. Biosci. Discov. 6(1), 45-48.

Kshirsagar, S. R., Patil, D. A., 2008. Flora of Jalgaon District, Maharashtra. Bishen Singh Mahendra Pal Singh, Dehradun. pp.41-376.

Patil, D. A., 2003. Flora of Dhule and Nadurbar District (Maharashtra). Bishan Singh Mahendra Pal Singh Deharadun, 53-649.

Perold, S. M., 1995. Studies in the Marchantiales (Hepaticae) from southern Africa. 8. The genus Plagiochasma (Aytoniaceae: Aytonioideae) and six local taxa. Bothalia. 25(1), 13-29.

Yadav, S.S., Patil, V. S., Mathew, V., 2003. Seven new flowering plant records from Khandesh Satpuda, Maharashtra State. Plant Archiv. 3(1), 129-131.

\section{How to cite this article:}

Khan, T. A., Khan, J. V., 2018. Diversity of genus Plagiochasma in Satpuda range of Khandesh Region, Maharashtra, India. Int. J. Curr. Res. Biosci. Plant Biol. 5(11), 50-55.

doi: https://doi.org/10.20546/ijcrbp.2018.511.005 